\title{
Ишметьева Е.Я.
}

\author{
Обзор патентной информации и источников \\ периодической печати по теме «Проектные решения \\ плана информатизации договорного отдела банка»
}

\author{
Ishmeteva E.Ya. \\ An overview of patent information sources and periodicals \\ on the topic "Design concepts of the plan of the \\ Informatization Department of the Bank"
}

Развитие информационных технологий дает возможность разработки новых программных продуктов, а именно новых автоматизированных банковских систем, модернизации уже существующих. В данной работе проводится анализ наиболее эффективных научно-технических достижений в области банковской деятельности Ключевые слова: патенты, изобретения, полезные модели, банковская деятельность

\section{Ииметьева Екатерина Яковлевна}

Магистр

Магнитогорский государственный технический университет им. Г.И. Носова

\begin{abstract}
The development of information technologies enables development of new software products, namely the new automated banking systems, modernizing existing ones. In this work the analysis of the most effective scientific and technical achievements in the field of banking
\end{abstract}

Key words: patents, inventions, utility models, system banking

\section{Ishmeteva EkaterinaYakovlevna \\ Master \\ Magnitogorsk state technical university named G.I. Nosov}

Был произведён анализ ряда патентов и заявок на изобретения и полезные модели зарегистрированные в Российской Федерации, а так же в США, Южной Кореи и Японии. Анализ показал, что каждая страна уделяет особое внимание развития банковского сектора.

Рассмотрим патент № 2549510 на изобретение «Системы и способы создания крупномасштабной архитектуры обработки кредитной информации». Он представляет собой систему повышения эффективности обработки больших объемов данных для генерирования отчетности. Система содержит систему управления информацией, включающую в себя модуль интерфейса для периодического получения множества наборов данных, память для хранения обработанных наборов данных и показателей, касающихся обработанных наборов данных. Система может быть интересна крупным банкам, база данных которых насчитывает свыше миллионов клиентов [1]. 
Заявка № 2009101202 на изобретение «Автоматизированная информационно-аналитическая система банковского кредитования предприятий-заемщиков» предназаначена для ведения электронного документооборота и содержит базовый банковский процессор с устройством цифропечати, базу данных кредитных историй предприятий-заемщиков и блок формирования кредитного рейтинга предприятий-заемщиков. Ее преимуществами является дополнительное содержание средств оценки стоимости нематериальных активов предприятия-заемщика, выполненное в виде сумматора учетной бухгалтерской стоимости активов, включающего электронный блок учета активов производственнотехнологического назначения [2].

Еще один патент № 493104 на полезную модель «Автоматизированная система предоставления банковских услуг» относится к области вычислительной техники, а именно, к комплексным автоматизированным системам для предоставления банковских услуг предприятиям, организациям и отдельным лицам, и может быть использована, в частности, для автоматизации работы банка, имеющего иерархическую и географически распределенную структуру. Достоинствами системы является эффективное и надежное управление филиалами банка, а также в обеспечении эффективного взаимодействия центрального офиса с офисами филиалов [3].

Так же, были рассмотрены свидетельства о государственной регистрации программ для ЭВМ, обеспечивающие управление банковскими операциями и документами.

Среди рассмотренных свидетельств, отдельно стоит выделить программный комплекс для ЭВМ «Автоматизированная банковская система «Операционный день МКБ 98»». Он предназначен для автоматизации банковской деятельности. Его функциональными возможностями и достоинствами являются: мультивалютный бухгалтерский учет; работа головного офиса и филиалов в единой базе, а также электронный обмен платежными документами с клиентами банка (Банк-Клиент) [4].

В отличии от ранее рассмотренной программы, программа «Модуль обслуживания заемщиков Фронт-офисной системы «Банковские Технологии»» позволяет интегрироваться с установленной в организации бэк-офисной системой для построения «сквозных» бизнес-процессов по сопровождению кредитов. Преимуществами программы является предусмотренная возможность обработки обращений клиента в рамках действующих договоров, и формирование сообщений в бэк-офисные системы для учета обращений по договору [5].

Так же, было приведено аналитическое исследование состояния проблемы по источникам российской и зарубежной периодической печати. Наибольший интерес по теме исследования представляют следующие работы.

В статье «Безопасность автоматизированных систем обработки информации банка» рассмотрены основные моменты защиты банковских систем от несанкционированного доступа. Недостатком этой статьи я считаю, что там нет конкретных решений выявленной проблемы [6]. 
В статье «Информационная поддержка при обеспечении защищенности систем интернет-банкинга» предложена модель информационной системы интернет-банкинга, использование которой позволит минимизировать количество атак киберпреступников, оптимизировать и совершенствовать комплексную систему информационной безопасности организаций экономической и социальной сферы. Достоинставами статьи являются предложенные решения, которые позволяют увеличить мощность информационной безопасности информационной системы интернет-банкинга, увеличить эффективность и качество принятия управленческих решений по защите конфиденциальной информации [7].

В данной статье были рассмотрены анализ патентной информации, а так же анализ источникам российской и зарубежной периодической печати на предмет планирования производства на предприятиях.

\section{Список используемых источников:}

1. Цветков Н.А., Алиев Д.Ф. Патент 49310 Российская Федерация, МПК G06F17/60.

Автоматизированная система предоставления банковских услуг. Заявитель и патентообладатель ОАО АКБ "Автобанк-Никойл". № 2005117075/22; заявл. 06.06.2005; опубл. 10.11.2005.

2. Патент 2009101202 Российская Федерация, МПК G06Q40/00. Автоматизированная информационноаналитическая система банковского кредитования предприятий-заемщиков. Заявитель и патентообладатель Михайлов О.И. № 2009101202/08; заявл. 16.01.2009; опубл. 27.07.2010.

3. Патент 2014127320 Российская Федерация, МПК G06F17/60. Системы и способы обработки кредитных данных микрофинансирования и представления отчетности по этим данным / АЧАНТА Венкат, ЛАССЕН Патрисия Черил; заявитель и патентообладатель Экспириен Инфомэйшн Солюшнз. № 2014127320; заявл. 27.02.2014; опубл. 27.01.2016.

4. Свидетельство о государственной регистрации программы для ЭВМ 2015614865 Российская Федерация. Автоматизированая банковская система «Операционный день МКБ 98» /правообладатель Открытое акционерное общество «Металлургический коммерческий банк». № 2015614865; рег. 29.04.2015; опубл. 20.06.2015.

5. Свидетельство о государственной регистрации программы для ЭВМ 2015661183 Российская Федерация. Модуль обслуживания заемщиков Фронт-офисной системы «Банковские Технологии» / правообладатель Общество с ограниченной ответственностью «Банковские Технологии». № 2015619955 ; рег. 15.12.2015; опубл. 20.01.2016.

6. Филина О.А., Мелькумяни А.А. Безопасность автоматизированных систем обработки информации банка // Вестник образовательного консорциума среднерусский университет. Информационные технологии. 2014. № 4. С. 57-59.

7. Тумбинская М.В. Информационная поддержка при обеспечении защищенности систем интернетбанкинга // Национальные интересы: приоритеты и безопасность. 2015. № 15(300). С. 48-58.

\section{(C) 2016, Ииметьева Е.Я.}

Обзор патентной информации и источников периодической печати по теме «Проектные решения плана информатизации договорного отдела банка»
(C) 2016, Ishmeteva E.Ya.

An overview of patent information sources and periodicals on the topic "Design concepts of the plan of the Informatization Department of the Bank" 